\title{
Derivatives and Capitalist Markets: The Speculative Heart of Capital
}

\author{
Tony Norfield \\ School of Oriental and African Studies, University of London \\ tonynorfield@gmail.com
}

\begin{abstract}
Financial derivatives have been singled out as the major villain in the latest crisis, particularly through speculative trading by banks. Yet little attention has been paid to the fundamental rôle that derivatives play in modern capitalism. Even less has there been a focus on how the boom in derivatives-trading was prompted by the crisis of profitability and capital-accumulation. This article shows that while derivatives were one means by which speculation took off, the momentum behind this was driven by low profitability. That was why banks turned their mortgage-loans into derivative-driven securities, why pension-funds placed bets on commodity-futures and why countries such as Greece used derivatives to hide the real state of their finances. Derivatives helped determine the form and magnitude of the crisis, but were not its underlying cause. Proposed reforms of the derivatives-market ignore the fundamental determinants of the financial crisis, assuming it to be a failure of regulation.
\end{abstract}

Keywords

derivatives, speculation, hedging, capitalist markets, financial crisis, rate of profit

\section{Introduction}

The aftermath of the crisis that broke in 2008 with the collapse of Lehman Brothers is clearly still with us. Unable to resolve the present crisis, governmentpolicymakers in the US, Europe and elsewhere are desperately trying to tighten up the regulation of financial markets to guard against a future one. The focus of the policy-plans is the derivatives-market, particularly derivatives related to credit-default. ${ }^{1}$ This article examines the rôle of derivatives in the capitalist

1. The US Dodd-Frank 'Wall Street Reform and Consumer Protection Act' was signed into law on 21 July 2010. This 848-page document has 161 pages specifically dedicated to regulating the swaps-market. On 15 September 2010, the European Commission adopted a regulation on overthe-counter derivatives-markets, implementing similar reforms. The EU Commission commented: 'The financial crisis has brought over-the-counter (OTC) derivatives to the forefront of regulatory 
market-system. ${ }^{2}$ It shows that derivatives are a natural development of capitalist markets, and that speculation is inevitable. Furthermore, by examining the development of derivatives as a function of problems in capital-accumulation, our argument is that derivatives are far from being the source of the problem. Derivatives will be shown to be just another tool used by capital in the major powers - especially in the US and the UK, the major banking giants - to try and overcome weak profitability. The rise of derivatives is not a sign of financial 'sophistication', computer-power and globalised markets, but of a desperate move by capitalists to find another channel through which to promote profits. ${ }^{3}$ In this context, calls for a reform of the derivatives-market are irrelevant at best.

The official focus on derivatives as the problem deflects attention from the underlying causes of the crisis and shifts it onto proposals to deal with capitalism's excesses. European governments in the past two years have been especially concerned with the credit-default swaps (CDS) area of the derivativesmarket. These swaps enable bondholders to take out insurance against company or country-default on their debt-repayments, and they have been important vehicles for speculation on the probability that default will occur. During 2011, European plans to deal with the Greek debt-crisis were dominated by how to bring a solution that avoided being termed a 'credit-event' that would trigger payments on credit-default swap contracts.

CDS took centre-stage as the derivatives-bogeyman for European politicians from late 2009. That was when it became all too clear what financial markets thought of Greece, a country that had fraudulently reported its finances to enter the euro. ${ }^{4}$ It is not difficult to imagine the frustration of euro-area

attention. The near-collapse of Bear Stearns in March 2008, the default of Lehman Brothers on 15 September 2008 and the bail-out of AIG the following day highlighted the shortcomings in the functioning of the OTC derivatives market. Within that market, regulators devoted particular attention to the role that credit default swaps played during the crisis.' See European Commission 2010, p. 5. The UK authorities questioned the proposed reform's details, but basically agreed with the overall approach. See Financial Services Authority 2009.

2. The author wishes to thank two anonymous reviewers for their helpful comments on an earlier draft of this article.

3. In my former career, I worked for some 20 years in bank dealing rooms in the City of London, running research-teams. During that time, when working for an American and, later, a European bank, I took positions in interest-rate swaps and futures, forward currency values, 'non-deliverable forwards' and a variety of 'vanilla' and 'exotic' currency-options. My observations of dealers and of bank-clients (non-financial corporations, pension-funds, hedge-funds, central banks, etc.) gave me an insight into the 'speculative' and 'real economy'-dimensions of the financial-derivatives markets.

4. It has been widely reported that a major US investment-bank, Goldman Sachs, was instrumental in managing a derivatives-focused programme for the Greek government to hide 
politicians with all this. Their plans for resolving the crisis might be blown up by the financial markets that they had previously encouraged. More critically, with the fragile finances of other euro member-countries coming under pressure, the political project of monetary union also came under threat. The frustration with derivatives has spread, even to the extent of a regular columnist on the Financial Times, newspaper of Europe's business-élite, calling for a ban on some forms of trading. ${ }^{5}$

This article begins with a brief note on how to understand derivatives, reviewing some of the recent literature. Sections 3 and 4 show how derivatives develop as a hedging tool within the capitalist market-system. Section 5 discusses how far it is possible to distinguish speculation from hedging. Section 6 situates the growth of derivatives in the context of declining profitability and crisis, and specific examples are given in Section 7 to illustrate the rôle of derivatives in commodity-speculation, the mortgage-debt fiasco and sovereigndebt crises. Section 8 analyses the rôle of deregulation and the proposed reforms of derivatives-trading.

\section{Where do derivatives fit in?}

The definition of a derivative is deceptively straightforward. It is a financial contract whose value is derived from something else. However, the capitalist market throws up a confusing array of 'somethings'. The value of the derivative financial contract could depend on anything from the price of copper, to the price of a particular financial security (a bond or an equity), to the temperature, to a default on a payment, to the price of another derivative-contract (as in the case of an option on a futures-contract). Or the derivative-contract's value may reflect the price of several other financial assets, or yet still other features that will affect its value. ${ }^{6}$ Whatever else it is, the derivative is not the underlying asset.

For example, the owner of a futures-contract to buy a tonne of copper at a particular price does not actually own the copper. She will only do so when the contract expires, for example in March 2012. Ahead of that time, the contract

the real state of its public finances from the EU authorities ahead of its membership of the euro in 2001. See Clark, Stewart and Moya 2010.

5. Wolfgang Münchau wrote: 'I generally do not like to propose bans. But I cannot understand why we are still allowing the trade in credit default swaps without ownership of the underlying securities... Naked CDS are the instrument of choice for those who take large bets against European governments, most recently in Greece.' See Münchau 2010. A 'naked' derivativesposition is one that is held by a trader with no underlying security to hedge.

6. See Hull 2009 for a comprehensive textbook on the mechanics of pricing derivatives, including weather-derivatives. 
may be sold and a profit or loss realised, given any price-changes in the copper to which she has a future title. A similar thing is true of all futures-contracts, whether on commodities or financial instruments or anything else. ${ }^{7}$ For options-derivatives, the owner of an option to buy a financial security at a particular price in June 2012 does not gain any dividend or accrued interest from ownership before the option is exercised because she does not own the security. All that is 'owned' is a contract to buy the security at a particular price up to the expiry-date (and the option would not be exercised if the relevant market-price was lower than the option strike-price). For interest-rate swaps derivatives, the counter-parties to a deal agree to exchange sequences of cashflows over a set period of time that relate to their existing assets or liabilities. They do not exchange the assets and liabilities themselves.

Given these features of derivatives, it is quite misleading for Bryan and Rafferty to argue ${ }^{8}$ that derivatives are 'commodities that play multiple monetary functions' and that their 'commodified commensuration is what makes financial derivatives fundamentally different from other paper titles, such as fiat money'. This 'commensuration' is simply the calculated value of the derivative, which is almost exclusively expressed in terms of a major currency, most often US dollars. There is no 'derivative-currency' unit of account, measured in pages of contract-terms, or with denominations determined by how far it is from the underlying asset-value. The commensuration comes through the fiat-money value of the derivative that Bryan and Rafferty claim derivatives have somehow transcended.

The so-called commensuration via derivatives is also particularly unstable because of the typically complex relationship between the value of the derivative and the price of the underlying security. In the case of bonds or equities, the underlying security's price is already the capitalised value of expected future revenues - what Marx called 'fictitious capital'. Here the 'money or capital value represents either no capital at all, as in the case of state debts, or is regulated independently of the value of real capital [in the case of equities, for example] which it represents'. ${ }^{9}$ A derivative on fictitious capital, as with bond or equity-futures and options, has a value that is regulated in yet another independent manner, even further removed from the underlying capital or commodity on which it is ultimately based.

7. For short-term interest-rate futures-contracts, however, on expiry one does not end up owning $3 \mathrm{~m}$ LIBOR, etc., but pays or gets a settlement in cash, depending on the difference between the settlement-price and the contract-price.

8. Bryan and Rafferty 2006a, p. 90.

9. See Marx 1974b, p. 468. This chapter has Marx's most useful comments on fictitious capital, and the distance between the concept of fictitious capital and real capital and commodities. 
Take the example of call-options, although similar arguments apply to all derivatives. The value of a call-option to buy a commodity or security at a certain future price will range from zero to an unlimited positive number of dollars. Another call-option with the same expiry-date and the same strikeprice for the same security might have a 'barrier'-condition attached to it. The condition may be that the second call-option is only valid if the security's price falls to a certain level over the next two weeks (a 'knock-in' barrier). They are both derivatives on the same security, but each derivative's value will be calculated very differently. ${ }^{10}$ This questions the validity of both the commensuration and of the claim that derivatives are a form of money.

Furthermore, because a derivative is not the underlying security, it has a limited time during which it is valid. It is no good if the underlying security's price is only at the strike-price or contract-price on expiry and ten per cent above it on the day after. The derivative would expire valueless because the bet is one day wrong. Even on depreciating dollar-bills, one does not have a March 2012 expiry-date. These features of derivatives are hardly ones that can mark them out as 'distinctly global money'11 or as 'distinctively capitalist money'. ${ }^{12}$ That opinion loses sight of some key rôles of money: derivatives give a quite unstable 'measure of value' as well as a very unsatisfactory 'store of value'. ${ }^{13}$

We would agree with Bryan and Rafferty that derivatives are an 'integral expression of capitalism'. ${ }^{14}$ However, their notion of derivatives seems to have been influenced more by the huge volume and diversity of derivatives-trading and its explosive growth in recent decades than by an examination of what has driven these developments. Writing before the crisis struck, the authors do allow for the risk that a financial crisis would have a 'pervasive and speedy impact' because of the global spread of derivatives. Yet they can also argue that the global financial system is 'regulated, in the sense of being kept orderly [sic], by processes and conventions in which derivatives play a central role'. ${ }^{15}$

10. For a comprehensive textbook on options, futures, swaps and other derivatives, see Hull 2009 .

11. Bryan and Rafferty 2006a, p. 93 .

12. Bryan and Rafferty 2006a, p. 77.

13. See also the remarks on Bryan and Rafferty's analysis in Lapavitsas 2006, p. 151, where he says that derivatives 'do not represent commodities, nor is there any clear sense in which they are money.'

14. Bryan and Rafferty 2006b, p. 214.

15. Bryan and Rafferty 2006b, pp. 208-9. Their book is a useful review of many aspects of derivatives and some of the relevant history. They also make the valid point that cross-currency interest-rate swaps, for example, may be used to reduce net funding costs for the counter-parties to the deal, rather than to act as 'insurance'. However, by failing to place derivatives in the context of capital-accumulation and crisis, they present a misleading idea of the rôle that derivatives play in the system. 
Implicitly, they allow for the rôle that derivatives play in helping spur capitalaccumulation, but they ignore the problems of capital-accumulation and falling profitability, and how these factors explain the context for the growth of derivatives in the first place. The analysis here differs by situating the rôle of derivatives in the context of capitalist crisis. ${ }^{16}$

\section{Market-risk and the need for price-insurance}

The origin of derivatives is found by considering the simplest form of commodity-circulation. The sale of a commodity for money and the purchase of another commodity with this money (C-M-C) bring a number of risks. If the producer of the first commodity cannot sell her output, she is stuck with a usevalue that has no exchange-value. If she can sell it, then she may receive less cash than she bargained for. With that cash, she may not be able to buy another commodity, either because the price is too high, or there is none on the market at any price. Or she may decide to hold on to the cash and not purchase anything, so that another commodity-seller will be disappointed. ${ }^{17}$

There are two broad areas of risk for any capitalist company. Firstly, that the demand for particular commodities may collapse or the supply of particular commodities dries up; secondly, that the price received by the seller of a commodity is 'too low' or the price demanded by the seller of another, needed commodity is 'too high'. Companies attempt to cover the first area of risk with various forms of supply-contract to deliver the products another company needs. It is the second area of risk that is our concern here, one focused specifically on price-levels.

If the prices paid for commodities bought and sold are such that a company can make no profit, then there is no point in producing. The reality of the capitalist market thus creates a demand for some form of price-insurance to cover against unexpected losses. Outside of commodity-prices, there are clearly other areas of commercial risk that companies face in their business-operations. Levels of interest-rates and exchange-rates are the most important. The more

16. McNally 2009 does provide a good analysis of the growth of derivatives in the context of the capitalist crisis. My article examines more closely the rôle of derivatives in the crisis and analyses more recent phenomena.

17. See Marx 1974a, p. 115: 'No one can sell unless some one else purchases. But no one is forthwith bound to purchase, because he has just sold... These modes [of motion in the phases of metamorphosis of a commodity] therefore imply the possibility, and no more than the possibility, of crises. The conversion of this mere possibility into a reality is the result of a long series of relations, that, from our present standpoint of simple circulation, have as yet no existence.' 
volatile these are, the more they can damage profitability. This is where derivatives come in.

The scale and scope of derivatives-markets have exploded in recent decades, but there are historical examples of derivatives-trading dating back to the midnineteenth century, and even to before the emergence of capitalism. ${ }^{18}$ Derivatives were initially developed for important agricultural and industrial commodities that had volatile prices. A much later development was in financial derivatives. These came to prominence in the early 1970s, with the break-up of the Bretton Woods financial system. Chicago futures-exchanges began trading currencies in 1972 and Treasury bonds in 1975. Several important futures and derivatives-exchanges were also set up in Europe (UK, Germany, France) after the dramatic moves in currencies, interest-rates, oil-prices, commodities, etc., in the 1970s. This corroborates our point that derivatives emerge from the instability of capitalist market-exchange. In Section 6 below, we trace how market-instability grows alongside the crisis of profitability.

\section{The core-demand for derivatives}

Derivatives are often seen as a tool that speculators use to make bets on prices. This view would appear to be supported by the fact that the largest share of trading in derivatives is done by financial companies, rather than by nonfinancial companies who might need to hedge commercial price-risks. For example, data from the Bank for International Settlements show that only four to 20 per cent of different derivatives-contracts were transacted by nonfinancial companies. ${ }^{19}$

However, the fact that financial companies do most derivatives-trading does not imply that derivatives exist only to satisfy the demands of speculators.

18. The Dojima Rice Exchange in Osaka, Japan, is considered to have been the first official futures exchange-market, beginning futures-trading in 1730. The Chicago Board of Trade traded the first standardised futures-contract in 1864. The London Metal Market and Exchange Company was founded in 1877. As another sign of the real-economy basis of futures-trading, the metalexchange's initial three-month forward limit for futures-trading originated with the length of time it took a steam-ship to arrive in London from Chile, bringing copper. See London Metal Exchange 2011.

19. The author made these calculations from BIS data (see the statistical annex of BIS 2010a) on over-the-counter (OTC) derivatives. For exchange-traded derivatives (ETD), the distinction made by US exchanges is usually between 'non-commercial' and 'commercial' transactions. Deals undertaken by companies with an exposure to hedge are designated commercial. Non-commercial deals tend to predominate in ETD trading as well. It is commonly assumed, though not justifiably so, that 'commercial' deals are hedge-related, while 'non-commercial' deals are more, or completely, speculative in nature. 
Financial companies themselves may also be using derivatives to hedge their risks, rather than simply to make a bet on price-movements. Banks and other financial companies - not just industrialists - are exposed to changes in interest-rates and exchange-rates that will impact upon the cost of their funding or the value of their future revenues. Hence it is a mistake to identify all financial trading with speculation. ${ }^{20}$ Furthermore, even if 'pure' speculators make up the bulk of derivatives-trading, this does not mean that the underlying demand for derivatives originates with such speculators.

This point can be seen from the following observations. Firstly, there are no significant markets for derivatives where there is a complete absence of commercial hedgers. This suggests that commercial hedging is a critical factor in such markets. Secondly, the history of derivatives-exchanges shows that trading will not develop if the contract that is traded fails to reflect the pricerisk faced by a wide range of commercial companies. When the derivativecontract fails to do this, then it will fail as a derivative because companies cannot use it to hedge their risks. This is so, even if the contract is 'easy to trade' and so is suitable for speculators. So this epitome of exchange-value, the derivative, has to have a commercial use-value. ${ }^{21}$ The core-demand for derivatives comes from economic agents who wish to hedge a commercial risk. It does not come from speculators.

\section{Speculation and hedging}

If 'non-speculative' demand is necessary to support derivatives-trading, why do trading volumes seem to be dominated by 'speculators'? The answer is found by considering the risk-management decisions of those doing the trading.

In the case of a company hedging its price-risk with derivatives, the position taken will offset the risk of a change in the price of the underlying asset or liability. Assuming that the contract is a precise hedge - in other words, the

20. The BIS distinguishes between financial companies, separating them into 'reporting dealers', the professional market-makers, and 'other financial institutions'. All trades are done with 'reporting dealers', but in every category of derivatives-trading (except CDS), the 'other financial' category has a greater volume of derivatives outstanding than the dealers have between themselves. See BIS 2010c.

21. See Pennings and Meulenberg 1999 for details of failed contracts for commodity-derivatives on commodity and futures-exchanges, and a fuller discussion of the essential features of a derivatives-contract. By definition, the over-the-counter (OTC) contracts between banks and their clients are also highly likely to be determined according to a bank's customer-demand. This is not to deny that banks want to sell products that are profitable for them and which may be bad for their clients, but there has to be a demand for the product from the bank's clients. 
maturity and payout from the derivatives-contract matches the price-risk exactly - there is no need for the hedging company to trade again. It holds the derivatives-contract to maturity. On maturity, the company will have a gain (or loss) from the derivative that matches the loss (or gain in value) on the underlying asset or liability. In these circumstances, a hedger would not have to trade frequently, or even more than once. Additional trades by the hedging company are only needed where the hedge needs to be altered because the value of the asset or liability that is being hedged has changed (for example, when the volume of a supply-order gets revised). The volume of trading by hedgers is limited by the scope of their regular business-operations.

The case of a speculator trading in derivatives is quite different. If a speculator buys or sells a derivatives-contract, there is no 'underlying position' of an owned asset or liability that is being hedged. The change in price of the derivative represents a change in the speculator's profit-and-loss account and there is no offsetting loss/gain from a separate asset. The speculator is managing a trading book, and will therefore change her trading positions in derivatives to fit the risk-profile that she wants. If her positions are losing value, she may want to place bets in the opposite direction to close out her exposure. She may also just change her mind about the direction of prices and become 'bullish' on a market that she had previously thought was going down. Or she may want to take profit on contracts that she had sold through buying them back.

The gap between the prices at which a professional trader agrees to buy and sell is an important part of gaining a trading profit, aside from betting correctly on the movement of the derivatives-price. For this reason, she might have only a small net exposure to price-moves and still make significant profits. Also, for this reason, the scale of trading undertaken by speculators is not directly related to the amount of their risk-exposure. Ten bets that the price will go up is more risky than 50 that they will go up and another 50 offsetting bets that they will go down, even if the latter volume of deals is ten times larger. ${ }^{22}$

Trading book risk-management makes it likely that the speculator (or 'noncommercial' trader) side of the market will engage in a higher volume of trading than the company-hedger side of the market. This is an inevitable and pervasive feature of derivatives-markets. It is also important for speculators to be present

22. The commonly used BIS data for the volume of derivatives-trading show huge numbers in the many trillions of dollars. However, the BIS itself notes that the scale of market-trading is not a good indicator of the scale of market-risk. See BIS 2010c, p. 9. At June 2010, the total notional amount of derivatives outstanding in the OTC market amounted to $\$ 582,655$ billion. But this was nearly 24 times the estimated $\$ 24,673$ billion 'gross market-value' that is a closer estimate of the market-risk. For example, an option to buy \$1m of a currency might have a market-value of only $\$ 5,000$, given the maturity and strike-price of the option. The $\$ 5,000$ is the gross market-value, but the $\$ 1 \mathrm{~m}$ is the notional amount of the option. 
in the market for such hedging to take place, and the history of derivativesmarkets shows that speculators are necessary for their effective operation. It is bound to be difficult for a particular company to find other hedgers with exactly offsetting risks. Here is where activity by 'market-makers' or speculative dealers is critical. In derivatives-exchanges, dealers have commitments to provide such prices as part of their membership-rules if they are designated as market-makers. In over-the-counter markets, outside the official exchanges, banks usually act as market-makers for their clients. This market-making is speculative, but without it the market will remain illiquid and not function. ${ }^{23}$

It is a mistake to identify all the trading of financial companies as the trading of 'speculators', since this will also include deals done to hedge their businessrisks. By the same token, the so-called 'commercial' or 'non-financial' companies will also do speculative deals rather than simply hedge. Accounting rules might attempt to determine whether a company's deal enters its 'trading book' or whether it can be classed as a 'hedge'. Yet there are many ambiguities here.

Firstly, note that a company that does not have any hedges for its marketprice exposure is effectively gambling ('speculating') that future price-moves will not damage its business. Companies thus tend to hedge their risks. The fact that access to hedging is easier and cheaper for the larger companies is also one element in the process of monopolisation of business. ${ }^{24}$

However, a company that has hedged its business-risks may decide to take the hedges off again. For example, it may have thought that there was a risk of a fall in the value of a currency that would damage its revenues. That fall may have taken place, so the hedge turned out to be profitable (offsetting the implicit loss on its commercial business). But the company may then unwind the hedge at a profit, believing no further fall is likely. Even if a company plans to be fully hedged, it will have some timing leeway (intra-day, intra-week or over the period to end-month, etc.) to pick the best levels of market-prices from which to buy or sell when conducting the hedge. This kind of small-scale speculation when dealing in derivatives is very common in corporate treasurydepartments. The biggest corporations are also active traders in derivatives,

23. A market's liquidity is reflected in how much a price has to move to get a deal transacted. It is also true that banks sell derivatives-ideas to their customers from the point of view of earning fees, and the deal may not be in the best interests of the customer. Examples of this have been popularised in numerous market-reports; see, for example, Das 2006.

24. Banks will offer hedging products to all companies, but the margins charged to the larger company will be lower and other terms offered will be less onerous. The larger company will tend to have a better credit-rating and be more important for the bank's business than the smaller company. 
competing with the banks and other dealers, and they usually have to meet profit-targets on their dealings. ${ }^{25}$

Companies may also make a policy-decision to hold out for better prices at which to hedge. They will then aggressively hedge when prices go to the desired levels. If that bet does not work, they might change their minds and panic to hedge if prices continue to move in the 'wrong' direction. Dramatic moves in market-prices can therefore result from hedging as much as from speculation. ${ }^{26}$

One cannot distinguish 'speculation' from 'hedging' by looking at the data for derivatives-trading from the BIS or from individual commodity-exchanges. Distinguishing 'financial' dealers from 'non-financial', or 'commercial' dealers from 'non-commercial', does not capture the motives for the transaction. ${ }^{27}$ But the problem goes beyond how to define or measure speculation. The real issue is that price-uncertainty and risk confront all agents in the capitalist market-system. Each must act in a way that will protect and expand company-profitability. All speculators will be hedgers and all hedgers will be speculators to some degree. ${ }^{28}$

\section{Capitalist profitability and the financial form of the crisis}

Our focus on speculation and derivatives is because the latest crisis took on a dramatic financial form. Major banks and other institutions became insolvent, money-markets seized up and governments abandoned their free-market rhetoric to try and rescue the financial system. Speculative bubbles, banking crises and crashes have characterised the history of capitalism, but a recent historical study has shown that the incidence of banking crises has risen since the 1970s, when the US and the UK relaxed controls on financial markets and demanded that others do so too. The study's authors remarked that 'the tally of crises is particularly high for the world's financial centres: the United Kingdom, the United States, and France.'29 This fact should lead to the conclusion that something systematic is going on. It is not just one accident after another.

25. These comments are based upon my observations of company-behaviour when working in banks.

26. In the author's experience, Japanese life-insurance companies, owners of a huge volume of US securities, have also caused sharp moves in the Dollar-Yen exchange-rate as a result of changes in their 'hedging ratio' for US bonds.

27. These are the standard definitions of different classes of trader that are commonly used as a proxy for distinguishing the speculators from the others.

28. A recent US Senate report into speculation also made the point that the line between speculation and hedging is 'exceedingly difficult to draw'. US Senate 2009, p. 54.

29. See Rogoff and Reinhart 2008. 
As far back as 1848, the political economist and philosopher John Stuart Mill made an observation that is still relevant today: 'Such vicissitudes, beginning with irrational speculation and ending with a commercial crisis, have not hitherto become less frequent or less violent with the growth of capital and the extension of industry. Rather they may be said to have become more so: in consequence, it is often said of increased competition; but, as I prefer to say, of a low rate of profit and interest, which makes the capitalists dissatisfied with the ordinary course of safe mercantile gains. ${ }^{30}$ This early statement of the reason behind speculation in the capitalist economy - a low rate of profit was developed in Marx's analysis of capitalism. Those who separate the financial crisis from the 'low rate of profit and interest' have taken a step back from the insight of John Stuart Mill. They are further still behind Marx's analysis of how a fundamental feature of capital-investment is the long-term tendency of the rate of profit on investment to fall. ${ }^{31}$ This tendency prompts capital to search for other means of gaining extra revenues, to depend more on the expansion of credit and to move into speculative activities.

What can appear to be a purely financial crisis is really the end-result of developments that emanate from problems capitalism has in producing enough profit. The origins of the financial form of the crisis we see today lie in the promotion of finance, particularly by American and British imperialism, and especially from the late 1970 s. $^{32}$ The policy-decisions of the US and UK governments to liberalise financial markets were based upon them seeing the financial sector as a key area of the global economy in which they had a competitive advantage. This advantage is based upon the British and US imperialist rôle in the world-economy, and it was an important option for them, especially given how difficult it was to try and regain industrial competitiveness. ${ }^{33}$ Thefact that the policies have persisted underadministration after administration, Republican or Democrat (in the US) and Conservative or Labour (in the UK) - with versions of these in other countries - shows the degree to which the financial policies are embedded in the core of the system. In

30. Cited in Kindleberger 2000, p. 34 .

31. The most systematic account of Marx's theory of the falling rate of profit, countertendencies and the relationship to speculation and crisis is to be found in Grossmann 1992. The book was first published in Leipzig in 1929, and this is an abridged, English translation by Jairus Banaji. The much longer German edition includes a final chapter that puts paid to any notion that Grossmann's analysis was mechanistic, or that he expected an automatic collapse of the capitalist system.

32. A rejection of previous so-called Keynesian economic policies and the promotion of finance started before the Thatcher and Reagan years, though it accelerated after 1979. Some UK-related examples are given in Norfield 2011a.

33. For a useful review of this topic, see Helleiner 1994. 
our view, the origin of these systematic policies can only properly be explained by capitalism's crisis of profitability.

The best way to illustrate this point is to examine US data. ${ }^{34}$ Calculations of the US corporate rate of profit show that there was a clear downtrend from 1945 until the 1970s, the decade that brought the most serious economic crises of the postwar period up to that point. There was some recovery of profitability on this measure in the decade from the mid-1980s, after the lows seen in the previous years. However, this still left the rate of profit below the crisis-related levels that were seen during the $197 \mathrm{os}^{35}$ (see Figure 1). After falling back again in the late 1990s, the rate of profit rose once more from 2001 to 2006. This time, there was a sharp spike in the reported profit-rate to higher levels than in the 1970s. But this recovery in profits was due to the biggest speculative bubble in US history. Much of the recorded extra profit will either have been a result of the credit-fuelled spending of the time, or will have reflected transient gains in financial market-values that companies reported as income. Not surprisingly, the profit-rate fell back quickly after 2006 when the bubble burst. ${ }^{36}$

Data for calculating a rate of profit for 2010 were not available at the time of writing, but they may show a higher rate than for 2009. This recovery (if it does appear in the data) should be seen in the context of huge US governmentindebtedness as it has taken on private-sector liabilities, and the policy-driven bounce-back in equity-prices that followed zero interest-rate levels. This is not a sign of flourishing capitalism.

The conclusion we draw is that the latest speculative-financial bubble began in response to the previous drop in profitability up to 2001. Interest rates fell in major countries and central banks expanded credit because growth and

34. The US publishes the most comprehensive statistics of all the major countries on corporate profits and fixed assets, and for the longest historical time-period.

35. I have been guided in the use of US economic statistics on profitability by the work of Andrew Kliman, who has covered the question of the long-term decline in the US rate of profit in detail; see, for example, Kliman 20og. However, the calculations and interpretations of the data here are my own. US domestic profits will have been boosted to some extent by expanded trade with China and other countries from the early 1980s, and from an attack on US working-class living standards, but this impact is difficult to estimate.

36. There were also profit-gains on the post-tax measure resulting from corporate tax-cuts. The measured rate of profit here is based on corporate profits divided by fixed capital-assets. Strictly speaking, the values of wages advanced and raw materials should also be included in the denominator, but these elements are not possible to calculate. Many other adjustments to the data should be made to better approximate a 'Marxist rate of profit', but these involve progressively more arguable assumptions. I do not argue that a fall in the rate of profit in one year produces a crisis in the next. The point is that the overall downtrend creates conditions for speculative activity to flourish, since more productive forms of capital-investment are unattractive. 


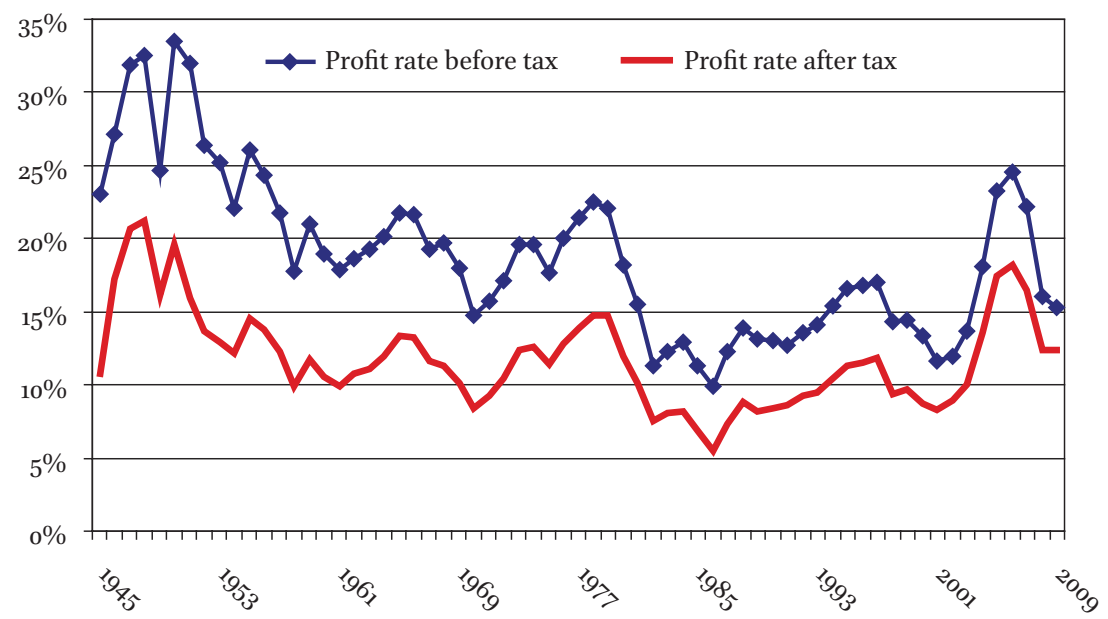

Source: Author's calculations from US Bureau of Economic Affairs data. NIPA Tables 6.17, line 1, and 6.19, line 1 for profits; Fixed Asset Table 6.3, line 2, for fixed assets.

${ }^{*}$ Note: Corporate profits in the current year are divided by the average of the fixed-asset stocks in the previous year and the current year. Fixed assets are measured at historical cost. The profits are for both non-financial and financial corporations in the US.

Figure 1. US corporate profit-rate, 1945-2009*

investment were very weak. ${ }^{37}$ This low growth and low profitability led banks and other corporations to look for other sources of profit. The result was to boost speculation. ${ }^{38}$

This was the era of 'financial innovation' and a swirling alphabet-soup of acronyms: ABS, CDO, CDO-squared, CDS, CPDO - and that is only a sample of the ones up to the letter C. ${ }^{39}$ Alongside the innovation - and the spur to it was a determined effort to find gaps in company-laws, tax-rules and regulation

37. In 2001-3, economic growth in the OECD area as a whole was less than two per cent compared to an average of three per cent in the previous 15 years. US growth was close to these averages; German and Japanese growth had fallen even more sharply to weaker levels. See OECD 2010, Annex Table 1. The decline in growth was under way before the September 2001 attacks in the US.

38. My view is that the overall rate of profit on capitalist investment tends to fall over time. It will move in cycles, depending on a wide range of factors, but the long-term downtrend will remain in place unless brought to a halt by a destruction of capital in war and a revaluation of investmentassets that boosts the rate of profit. The chart does not show the pre-1945 data, but in the early 1930s, before World-War II, the US rate of profit on this measure ranged from $-2 \%$ to $+5 \%$.

39. Crotty 2007 is a valuable analysis of how 'innovation' is a factor in bank-profitability. It got so bad in the latter stages of the boom that one City analyst hit out at another trend to create 'funds of funds' for investors (supposedly to spread risks, but really to gain fees), and then 'funds of funds of funds'. This, he said, ended up with 'F-all'. 
that could be used to increase profits. Corporations did not invest in productive activities that offered few returns and would not excite shareholders. Instead, they turned to financial 'engineering' and 'produced' much more money that way. All went well, and, for a while, extremely well. After 2006, the stretched elastic of financial and credit expansion snapped back..$^{40}$

The rôle of derivatives in the latest crisis was to help extend the speculative boom. In that sense, they made the crisis worse than it might otherwise have been, especially since the deals spread far beyond the US, overcoming any more local barriers. However, derivatives did not cause the crisis, they merely gave it a peculiar intensity and financial form. Low growth and low profitability were the reasons for the boom in derivatives-trading and 'financial innovation'. Alongside other aspects of the credit-system, derivatives can help promote capital-accumulation by saving companies transaction-costs, by giving the impression that risks are lower than in reality, by appearing to represent wealth that can be used as collateral for loans and by generating recorded profits based on speculation-driven prices. ${ }^{41} \mathrm{~A}$ blip in the system, a loan that does not get repaid as expected, can then trigger a financial collapse as it calls into question the assumptions behind a myriad of other deals. This is what is really meant by a 'lack of confidence' in financial markets: a fear that the expected values are illusory. The financial collapse impacts upon the 'real' economy, as credit is withdrawn and the funds lent by banks dry up, even to previously viable companies. The end-result is a worse crisis, when it finally occurs.

\section{Examples of speculation, derivatives and crisis}

In this section I examine three topics to give more concrete examples of the rôle of derivatives. These will show how that rôle came about because of weak profitability and the problems of capital-accumulation.

\footnotetext{
40. This is shown most clearly in the rise and fall of leverage-ratios, especially for financial companies.

41. In this sense, derivatives and financial-system trading is not a 'zero-sum game' for capitalaccumulation, despite operating in the sphere of circulation. Consider a simple non-derivatives example. If a company issues shares whose price then rises, buyers have made a capital-gain. But the company's 'loss' (it could have sold at a higher price) is also a gain. Its market-capitalisation is higher and this is collateral for investment-loans from banks or other borrowing from capitalmarkets.
} 


\subsection{Institutional speculators in the commodity-markets}

US government-hearings have examined many examples of futures-market turmoil in the past decade. ${ }^{42}$ When the oil-price moved up from $\$ 90$ to $\$ 150$ in the first half of 2008 and then slumped down to $\$ 40$ by year-end, even the most anti-regulation US lawmaker was concerned about market-stability and the potential for damage to the economy from speculation. What has particularly gained attention in recent years has been the influx of much more capital into commodity-markets, with accompanying signs of increased price-volatility. Commodity-derivatives markets are much smaller than the markets for financial derivatives. This means that the impact on prices of a billion dollars invested in commodity-derivatives is large compared to the impact it would have in foreign-exchange or interest-rate markets.

One witness testifying to a US Senate Committee noted that in recent years there had been a 'new category of participant in the commodities futures markets: Institutional Investors.' 43 These included company and government pension-funds, university-endowments, sovereign-wealth funds and other institutional investors. This is interesting as a counter to the popular picture of speculators as outrageous gamblers after a fast buck. However, he called these funds 'speculators' because they bought futures-contracts hoping for priceincreases, rather than using futures as a hedge. This is technically correct, but the fact that the funds are long-term investors in commodities does not sit well with the usual understanding of a speculator.

A large number of global pension-funds and other institutional investors bought into commodities from the early 2000 s because the returns on regular financial investments that had been their core-assets (bonds, equities) were poor. Major equity-markets had plunged in value by some $5^{\circ}$ per cent or more between 2000 and early 2003, and long-term bond-yields had fallen to levels significantly below those prevailing in the 1990s - certainly in nominal terms, but also in real, inflation-adjusted terms. ${ }^{44}$ While the lower bond-yields delivered capital-gains on existing bond-holdings, they meant that new bond-

42. In the period 2006-9 there were US Senate committee-investigations into oil, gas and wheat-price speculation. One earlier example of speculation was the attempt by the Hunt brothers to corner the silver-market in the 1970s. Today's speculation is far more broad-based, involving vast sums of capital.

43. See the evidence given to a US Senate committee-hearing on commodity-price speculation by a US fund-manager, Michael Masters (Masters 2008). I would disagree with a number of the assertions made in his article, but the overall picture of institutional involvement in commodities is correct, and there are some useful estimates of the quantity of fund-assets involved in these markets that I cite below.

44. Equity-price indices calculated for the US, UK and Germany from data available from Dailyfx.com. For interest-rate trends in major countries, see Homer and Sylla 2005, p. 668, Table 90. 
investments were progressively less attractive. This made commodities look compelling as an alternative 'asset-class'. This decision to move into commodities was classic portfolio-management strategy: look for a new asset that has good potential returns and whose price has a low correlation with existing assets. This improves the risk-reward profile of the total portfolio. The scope for future commodity-price increases was seen in the predictions of extra demand coming from Asian countries, especially China, as growth raised living standards.

So pension-funds and other long-term investment-funds moved into commodities. From a relatively small $\$ 13$ billion at the end of 2003 , the assets allocated to commodity-index trading strategies rose twenty-fold to $\$ 260$ billion by March 2008.

These institutions only allocated a small proportion of their assets (generally less than five per cent) to commodities. This was far from a case of 'betting the ranch' and tallied with their conservative investment-approach. However, a small share of a huge asset-value nevertheless adds up to a very large sum of capital. The funds also bought futures-contracts rather than the commodity itself. Instead of the trouble of storing barrels of oil, bushels of wheat and live cattle in the company car-park, they could simply 'roll over' the futures-contract into the next period before it expired, rather than accepting physical delivery of the goods. ${ }^{45}$

One of the major global pension-funds is Stichting Pensioenfonds ABP, based in the Netherlands and responsible for the pensions of 2.8 million government and education-workers. Its objective is to deliver an annual return of $7 \%$ on investments - not easy when government-bond yields were much lower. ${ }^{46}$ It moved into commodities in the early 2000s, and by end-2009 was investing almost $3 \%$ of its $€_{2} 60$ billion funds - close to $€_{7}$ billion - in this 'asset-class'. Another major fund, CalPERS, the California Public Employees' Retirement System, has investment-assets of close to $\$ 200$ billion at end-2009. It manages retirement-benefits for some 1.6 million people and also began investing in commodity-derivatives in 2007. Its 2008 board-meeting expressed the long-term aim of allocating up to $3 \%$ in commodities. ${ }^{47}$ The Ontario Teachers' Pension Plan, which manages pensions for 289,000 active and retired

45. This led to an oddity in the commodities-markets that baffled observers: the demand emanating from rolled-over long-futures positions did not draw down the level of futuresexchange stocks. So prices had increased without the higher demand versus supply showing up in lower stocks.

46. See ABP Investment Objectives, n.d.

47. See CalPERS 2007 and Kishan 2008. 
teachers in Canada, also got involved in commodities and had C $\$ 1.9$ billion, nearly $2 \%$ of its net assets, invested in commodities at end-2009. ${ }^{48}$

The move into commodity-derivatives by pension and other investmentfunds was the result of low returns on their financial investments, not some sudden desire to gamble on commodity-prices. Those low financial returns stemmed from declining profitability in the system as a whole. It is clearly unsustainable for capitalism to have high real rates of interest when the system's profitability is low. ${ }^{49}$ The impact was to drive a range of commodityprices higher and to exacerbate market-volatility. But the funds' aim was to maximise the profitability of their investments, limit their member's contributions and generate returns to pay pensions and other income. ${ }^{50}$

\subsection{Bank profitability, CDOs and CDS}

The US mortgage-debt crisis and its spread around the globe via derivatives has been extensively discussed. ${ }^{51}$ Here it is worth covering only the aspects that relate to our arguments about derivatives-trading.

From the 1970s, US banks created securities from the payments they received from holders of mortgage-debt. By the late 1980s, other forms of loans and debts to banks were also securitised, resulting in collateralised debt-obligations, or CDOs. The advantage for banks was that this was a mechanism to boost their earnings and profit-potential. They could sell the securities to investors,

48. See Ontario Teachers' Pension Plan 2009, p. 108. They also note the fall in real interest-rates on p. 15 .

49. The rate of profit for capitalist companies in the productive sector of the economy, the yields on bonds and the dividends paid from company shares are different things, with different drivers. However, the productive sector is the originator of the surplus-value that is redistributed via the financial markets to enable the payment of interest and dividends. In our view, the factor determining the trend to lower financial yields was the underlying fall in the rate of profit. By contrast, Duménil and Lévy 2004 base their thesis of financial domination on the higher real interest-rates of the 1980s, following the change in US monetary policy after 1979. But they fail to comment on or explain the fall in real interest-rates from the late 1980s into the 1990s (despite their Figure 9.1 running to 2001 (Duménil and Lévy 2004, p. 70)). Real interest-rates fell still further in the 2000 .

50. This is not the place to discuss what a socialist pensions-policy might look like. We simply wish to highlight an area of finance that is often ignored. There are many pension and endowmentfunds that have investments in all kinds of assets aside from bond and equity-holdings. Apart from commodities, they include investments in real estate, timber, infrastructure, private-equity funds and hedge-funds. These are not always successful. In the year to mid-2009, Bloomberg reported that Harvard University's endowment-fund lost some 30 per cent of its value, partly due to a switch into private-equity investment. See Wee 2009 .

51. See, for example, McNally 2009 and dos Santos 2009 for useful coverage of this topic. Das 2006 provides a readable account of the technicalities of the securities discussed in this section, including the different credit-'tranches' of CDOs that we will not discuss here. 
receive cash and have fresh capital with which to fund a new round of business. Essentially, this was how banks used derivatives to shorten the period of circulation of capital to boost profitability by not having to wait until the mortgages were fully repaid. From an estimated $\$ 68$ billion in 2000, global CDO issuance increased nearly seven-fold to a massive $\$ 456$ billion in $2006 .{ }^{52}$ Alongside this, financial-sector profits more than doubled over the same period. ${ }^{53}$

The new securities were designed to take advantage of laws on taxation and rules for bank-capital adequacy set by government-regulators. This was done in a way that minimised the banks' use of capital and maximised potential returns on capital. This might involve setting up a special-purpose vehicle (SPV) that becomes the owner of the loans, issues the CDO and pays the bank from the revenues it receives. ${ }^{54}$ The result was a massive issuance of such securities by US banks and their sale all around the world. This made the US sub-prime mortgage-debt crisis a global event.

As already noted (see Section 7.1), the early years of the new millennium were characterised by low yields on equity and bond-markets. By comparison, the securities based on US mortgage-debt looked attractive to a wide range of investors, both in the US and beyond, yielding some two to three percentagepoints of interest above similarly-rated corporate bonds. The fact that the US banks had a far better idea of the actual (worse) credit-risk of the new securities than the ratings-agencies or their investors was another way in which they profited from the transactions. There have been many reports of how the credit-ratings of such securities were inflated before being sold to investors, and there was no doubt a large element of fraud in this business. ${ }^{55}$ However, the investors were for the most part 'professional players' and were enticed into the new market by its offer of an escape from the low-yield environment that threatened their business.

The collapse in value of the CDOs had nothing directly to do with the derivatives-market. It was due to rising mortgage-defaults that prompted a drastic downgrade of credit-ratings as the economic crisis unfolded and

52. See SIFMA 2011.

53. In 2000, profits of the US financial corporate sector were $\$ 206.1$ billion, rising to $\$ 427.6$ billion in 2006. US non-financial corporate profits also rose sharply, nearly doubling to $\$ 923.9$ billion, helped by the reduction of interest-payments as rates fell and by credit-fuelled economic growth.

54. See Das 2006, Chapter 9.

55. Perhaps the most infamous example was where the US SEC sued Goldman Sachs for allowing one of its hedge-fund clients to choose the mortgages in a CDO that were then sold to other investors. The hedge-fund made $\$ 1$ billion by betting that the credit-rating of the CDO would slump. See Gallu and Harper 2010. 
real-estate prices fell. Where the derivatives-market did play a rôle in this, however, was through the medium of another acronym, CDS.

Credit-default swaps (CDS) started life in the early 1990s, but the easing of US bank-regulations after 1996 led to a boom in the growth of this financial derivative. They are a form of insurance-contract, where the CDS buyer pays an annual premium and receives compensation from the seller in the event of a default on payments. The payments may be for a company's bonds, for local and national government-debts or for CDO securities. Data on CDS derivatives show that in mid-2001 the notional amounts outstanding were $\$ 631.5$ billion, but this multiplied by a factor of 92 by the end of 2007, to an astonishing $\$ 58,244$ billion. ${ }^{56}$

The reason behind the extraordinary growth in CDS contracts was the same as for CDOs: they enabled banks to expand their profitability. But they did so in a different way. If banks were selling CDS, they would earn fees. More importantly, their purchase of CDS would enable them to save capital. ${ }^{57}$ The debt-securities on their books that had a weak credit-rating demanded significant capital-reserves to offset the risk that the debtors might default. With that default-risk reduced by the CDS insurance-contract, the required capital-reserves could be cut and the funds 'set free' to use for further businessexpansion. Much of the credit-risk reduced in this way was the risk from CDOs.

This mechanism accelerated the growth of the US banks' mortgage-business alongside the growth in volume of CDO and CDS deals. They were very closely intertwined. What also helped spur this dramatic growth was the delusion of low credit-risk, with the US economic recovery after 2001 and continued low interest-rates. The growth-recovery appeared to make mortgages less risky, and low interest-rates made them more affordable. This opened up the route into sub-prime lending. One study has shown that by 2006 the banks had run out of borrowers with much ability to pay back loans, so they delved ever more deeply into the sub-prime risks. ${ }^{58}$

56. See ISDA 2001 and BIS 2010c. Following the crisis in 2007-8, the scale of this market slumped by nearly half to 'only' $\$ 30,261$ billion by June 2010 .

57. See dos Santos 2009, p. 202; Levine 2010, p. 5, on the capital-saving aspects. BIS data show the banks buying and selling huge volumes of CDS, but generally being net buyers (the figures are closely matched). See BIS 2010c, p. 19, Table 4. AIG, the large US insurance-company later taken over by the US government, was also a huge seller of CDS 'insurance', helped by its former AAA top-rank credit-rating. A high credit-rating is necessary for your insurance to be valuable to a CDS buyer.

58. See Barnett-Hart 2009 for a detailed investigation of the credit-quality of CDOs, including an exposé of the rôle of the banks and ratings-agencies in inflating the credit-ratings of these securities. Her analysis shows that one important factor in the drop of credit-quality was the 'vintage' of the loan. Here we do not need to go into the associated practices of 'self-certification' 
We can see, then, that CDS were catalysts in the growth of banking and financial capital. The demand for them was both for financial insurance and as a way for banks to adjust their credit-exposure to customers, but this demand grew dramatically because it was also a means to expand profitability at a time when low interest-rates were threatening to damage bank and investmentrevenues.

\subsection{Sovereign-debt crises and CDS}

Credit-default swaps had also been written on the risk of countries defaulting on their debts since the late 1990s. However, in the early period, the CDS related to countries such as Indonesia, Thailand, South Korea, Russia, Mexico and Brazil. The only major capitalist power with any significant volume of CDS written on it was Japan, given the financial market's worries about its prolonged stagnation and its large and rising public-sector debt. When a crisis loomed, as in a number of Asian countries and in Russia in 1997-8, speculators would of course be attracted to buy the CDS. However, this kind of financial-market activity did not cause a stir in official policy-circles. The most significant thing that happened on this score was that the industry-group, the International Swap Dealers' Association (ISDA), changed the rules on sovereign CDS contracts in 1999 and thereafter, to clarify the terms of default and paymentdetails. ${ }^{59}$ The real worries about financial markets betting on sovereign default only began after 2008, when attention turned to the economic plight of countries much closer to one of the centres of global power: Europe.

This is not the place to discuss the underlying causes of the financial trouble in European countries, except to note the points relevant to the argument of this article. ${ }^{60}$ In summary, the shockwaves from the US sub-prime crisis after 2007 spread around the globe and into Europe, both because many European

and 'NINJA' (no income, no job or assets) mortgage-loans of banks that desperately tried to drum up more business.

59. See Das 2006, pp. 279-81. The other significant thing at this time was the financial crisis (mainly limited to the US) caused by the collapse of the major US hedge-fund LTCM in 1998. LTCM had started out by arbitrage-trading between similar securities and made strong returns, but it grew larger and found that higher profits depended on hugely leveraged trades using derivatives in a wider range of securities. The Russian credit-default caused only a minor panic in the markets, but it made previously strong statistical relationships break down. This destroyed LTCM's trading strategy and led to its demise. The 1997 Asian crisis, by contrast, had little relationship to derivatives. It was triggered by a slowdown in capital-accumulation, rampant speculation and then a reversal of short-term inflows of funds that had been attracted by high local interest-rates.

6o. A useful review of the situation leading to the economic troubles in the euro-countries is given in Lapavitsas, Kaltenbrunner, Lindo, Michell, Painceira, Pires, Powell, Stenfors and Teles 2010. 
banks and financial institutions had bought into the related 'toxic assets' from the US and because of the vulnerability each country already had from its own version of the financial and credit-bubble of the previous seven years. High and rising levels of consumer credit-card debt, property-market speculation and easily available bank-loans were common throughout the euro-area countries and beyond, especially in the UK. The credit-crunch put economic growth into reverse, while the drop in tax-revenues and huge bail-outs for the banking system led to a sovereign-debt crisis for the weaker euro-states.

Given this course of events, it makes little sense to judge that CDS were the cause of the sovereign-debt crisis. The old cliché of 'shooting the messenger' comes to mind. The CDS market's signals that there was a higher risk of a country defaulting on its debt were reflections of reality, not its cause. In the case of Greece, the country first in the default firing line, ISDA noted that the volume of positions on Greek sovereign CDS had barely risen from 2009 to early 2010. In any case, the $\$ 9$ billion volume of positions was barely two per cent of the value of the Greek government-bond market (in excess of $\$ 400$ billion), and it could not reasonably be argued that the CDS market was driving Greek government-bond market prices. ${ }^{61}$

Neither is it valid to argue that so-called 'naked' CDS should be blamed (that is, CDS contracts held by those who do not hold government-bonds). These are part of the total of contracts registered, and these CDS buyers could well have other claims on the government (for example through profitable valuations on interest-rate swaps) or claims on the private sector that would be at risk if the government defaulted. They may not have been speculating. Even if it were found, contrary to the evidence, that there had been a huge build-up of speculative CDS positions, then that would still simply be a response to a crisis that was plain for all to see.

All the evidence shows that the Greek debt-crisis has been long in the making. The root-causes were a mixture of widespread tax-evasion, the misuse (since the 1980s) of EU development-funds to finance current governmentspending, a private-sector credit-boom based on borrowing rates not far above Germany's after joining EMU in 2001, and declining competitiveness. ${ }^{62}$ The Greek government - assisted by Goldman Sachs and other banks - used

61. See ISDA 2010. The ISDA press-release is also correct in noting the fact that if speculators drove up the credit-risk on Greek bonds beyond the yields seen in the cash-market, then arbitrageactivity would lead to the spread falling back again. There are debates about whether the transparency of the derivatives-market, despite its small scale, means that it can drive cashmarket prices. But for Greece there is no case for arguing that CDS caused the crisis.

62. See Norfield 2011b, where it is noted that a large proportion of foreign debt to banks is owed by the Greek private sector. 
derivatives to hide its weak finances and qualify for EMU. Derivatives were Greece's cover for its failure to develop as a successful capitalist economy. That is a result of the nature of capitalism today (and economic and political corruption in Greece), not the excesses of the derivatives-markets.

\section{Derivative dynamics, regulation and reform}

The explosion of derivatives-trading has been associated in the literature with specific regulatory changes, especially in the US. With the outbreak of crisis and the finger put on derivatives-markets, government-committees and other agencies have discussed what mistakes were made in previous rules for derivatives-trading, and what changes should be made in order to avoid future crises. This has led to some surprisingly frank criticisms of the key authorities. Five key elements of regulation-mistakes that have been identified are:63

a) Regulators did not respond to clear signs in the early 2000 s that creditratings agencies were profiting a great deal from 'greasing the flow of structured products with optimistic ratings' and they continued to rely on the major ratings-agencies;

b) In 1996, the US Federal Reserve allowed banks to use CDS contracts to reduce their required reserves of capital; it then did nothing to regulate the market as the volume of CDS derivatives exploded and there was a concentration of counterparty-risk (for example, AIG had exposure to some $\$ 500$ billion of CDS and other derivatives, compared to its capital of just $\$ 100$ billion);

c) The US Federal Reserve, Treasury and SEC blocked calls for more 'transparency' in the OTC derivatives-market and backed legislation to keep this market unregulated. Congress passed the Commodity Futures Modernization Act of 2000, and one consequence of this Act was the so-called 'Enron loophole' that allowed energy-commodities to be traded on non-regulated exchanges;

d) In 2004, the US SEC allowed investment-banks to use their own models of market-risk to compute how much capital they needed to hold against risky securities they held as assets. (Guess whether the banks over- or under-estimated the capital needed!);

e) The US CFTC, in charge of regulating futures-markets, allowed investmentbanks a 'swaps-loophole' whereby they could use futures to 'hedge' their

63. See Levine 2010 for points (a) to (d); Greenberger 2008 for point (c), Masters 2008 for point (e). 
positions with clients. This enabled hedge-funds, pension-funds, etc., to accumulate market-positions, via the investment-banks, that were well above the regular position-limits allowed for speculators.

Such criticisms come from people who would be far from considering themselves anticapitalist. Their focus is on what they consider either to be policy-mistakes, or reasonable policies with unintended consequences, or even policies that they suspect were deliberate concessions to political supporters. The point of their critiques is to try to correct the 'mistakes' and prevent a recurrence of similar crises. ${ }^{64}$

The regulation-changes noted above were critical in the growth of derivativesmarkets, and they helped generate both the scale and the global breadth of the financial crisis that broke in 2007-8. However, this leaves an important question unanswered: why were the rules changed?

The rules were changed because that made sense for the dominant section of US capital. For the US Federal Reserve, the Treasury and the Securities and Exchange Commission to back a particular policy, and for that policy to be supported in the US Congress surely implies that the policy itself has the backing of a powerful section of the ruling class, even if there are some dissident voices. Not many people would start with the premise that capitalists are omniscient, so the fact that a widely-backed policy turns out to end in tears is no proof that it was a gamble to benefit a narrow élite of financiers.

More broadly, the rationale for the US authorities to 'back the bankers' rests on the key rôle that finance plays for the US's imperial position in the global economy. New York is the world's biggest capital-market, in terms of raising debt and equity-funds for companies, and the US is the second biggest foreignexchange market (after the UK). Consider also the tool of financial sanctions that US imperialism can implement through its influence over global banking against countries, such as Iran, that step out of line. ${ }^{65} \mathrm{~A}$ similar policy-stance is true for the UK government, though it does not have as much power to lead key changes in policy or much ability to work outside of cooperation with the

64. Following his blistering critique of regulatory failures, Levine 2010 proposes to establish a 'sentinel' with powers to gather information: 'The only responsibility of the Sentinel would be to deliver an annual report to the legislative and executive branches of government assessing the current and long-run impact on the public of financial regulatory and supervisory rules and practices.' This is probably a non-starter, but other policies to restrict the amount of bank-'leverage' and increase the amount of capital that banks must hold for their operations (Basel III) are to be implemented.

65. US and UK financial centres dominate the global markets in virtually all financial products. ILO data for 2006 indicate that five per cent of the US workforce is employed in 'financial intermediation'. 
US. ${ }^{66}$ Policy mistakes can, of course, be made. However, the repeated policies favouring finance that come from the centres of global finance - the US and UK - show that their stance is not a mistake. It is a deliberate and conscious strategy of the ruling class that is based on their considered assessment of what makes their economies tick. ${ }^{67}$

That is why the latest government reform-proposals for the financial system are not a sign of either the US or UK changing course, despite the political and economic shock the crisis produced. ${ }^{68}$ The proposals are attempts to install fire-doors in an earthquake-damaged skyscraper. Reforms for derivatives are based on putting OTC trading through a central clearing system, so that ownership and volumes can be monitored (made 'more transparent'). Where possible, trading will also be put on to electronic exchanges, to make dealing and pricing observable. Implementation is due by the end of 2012, but already there are disputes between major countries over the all-important details (including who bears the potential clearing-house losses, who decides the margin-requirements, brokerage-fees, etc.) that will have an impact on the business and competitiveness of each country's banks and investment-funds. ${ }^{69}$ To put these proposals in perspective, it is worth briefly noting some factors that suggest the system cannot be reformed:

1) The top three credit-ratings agencies still control 95 per cent of the market, four years after an apocalyptic screw-up. There are few signs yet of any competition building in this financial fiefdom. This is a characteristic of supposedly innovative and competitive financial markets: existing monopolies are rarely competed away.

2) Shifting OTC derivatives-trading onto exchanges might assist the regulation of trading, but it overlooks two things. Firstly, the exchanges themselves have been sources of wild speculation on many occasions in the past. Secondly, squeezing over-the-counter trades onto exchanges is bound to

66. UK statistics indicate that the UK financial sector accounts for only around one million jobs (some $3-4 \%$ of the workforce), but some $7 \%$ of GDP and $11-12 \%$ of total tax-revenues. In other words, a high-value sector of the UK economy. Price Waterhouse Coopers produces a regular report on financial tax-revenues for the City of London giving the tax-information (see Price Waterhouse Coopers 2010). London is the world's most diversified banking centre, with the largest foreign-exchange market.

67. See Norfield 2011a for an analysis of how the financial sector is key for the economic position of the UK, providing significant revenues and financing the profitable export of direct investment capital.

68. For the Basel III rules, a good summary of proposals to regulate bank-leverage and redefine bank-capital, etc., is found in BIS 2010 .

69. See the Financial Times editorial 'Swaps bickering', 10 July 2011. 
cause problems: the OTC market caters for client-specific deals and is roughly eight times the size of the ETD market, which is much more standardised. The shift is unlikely to be achieved, given the different rôles each market plays.

3) New regulations will no doubt offer some other loophole that will, in time, be exploited by capital's accountants, tax-lawyers, bankers, financecompanies and corporations. Damaging speculation does not depend on a particular form of derivatives-trading, or even on derivatives at all. The momentum behind the growth of derivatives-trading and speculation comes from problems in the wider capitalist economy: low profitability.

4) To highlight this, yet another 'financial innovation' has become the latest (mid-2011) worry for regulators: synthetic exchange-traded funds. ${ }^{70}$ These allow illiquid securities on a bank's book to act as collateral for the fund that does not necessarily invest in the securities that investors think it does. Confused? It is all fully explained on page 94 of the terms and conditions.

5) Then there is the question of valuing derivative-positions. When banks used their own models to value OTC derivatives, this led to self-serving calculations and idiotic interpretations. For example, in the wake of one phase of financial panic, Goldman Sachs's chief financial officer claimed that he was 'seeing things that were 25 -standard deviation moves, several days in a row. ${ }^{71}$ It has been pointed out that the probability of a single 25 -sigma event is comparable to the probability of winning the lottery 21 or 22 times in a row, ${ }^{72}$ a fact that more simply expresses that his risk-valuation model was, to be polite, flawed. Some of the latest reform-proposals suggest that regulators should employ risk-models instead. If so, then they would have to contend with the difficulty, not to say impossibility, of building a decent model, aside from having the expertise to do it. ${ }^{73}$ It is not simply a problem of getting prices and other data for illiquid securities, of gauging the risk of markets seizing up when you need to buy or sell, or of solving the mystery of how to value derivatives on derivatives of fictitious capital. The markets the models are meant to quantify are also fragile, crisis-ridden and prone to frequent régime-changes.

70. See Bank of England 2011, pp. 13-15.

71. See Larsen 2007.

72. See Dowd, Cotter, Humphrey and Woods 2008.

73. In my own professional experience, I had a maths-graduate 'quant' working for me to build a foreign-exchange model where the important feature was the value of a particular variable's coefficient. After he told me what it was, I questioned the calculation and found that he had mixed up the dependent and independent variables. He later went to work for Citigroup. 
It is worth knowing what the enemy is up to, but there is no upside for critics of the capitalist system to get involved in this debate about the details of financial reform. As Barack Obama said in a different context, 'You can put lipstick on a pig, but it is still a pig.'

\section{Conclusions}

The growth of derivatives-trading in the past decade or so was facilitated by changes in government-regulation. But the fundamental reasons why derivatives-trading exploded have more to do with the attempts by banks, finance-companies and corporations to boost their flagging profitability and revenues. 'Financial innovation' was an easier way to make money than productive investment. Derivatives helped postpone the crisis by adding fuel to a speculative boom, but they made the crisis worse. Governmentpolicymakers are now planning reforms to guard against another débâcle, but agreement between competing countries is not assured, even on what looks like a common problem. In any case, the reforms are unlikely to make much difference to the crisis-prone system, and already there are concerns about new kinds of speculative trouble. Whatever happens on this score, attacks on living standards to restore profitability will be a key tool of state-policy.

It is surely a sign of the decrepitude of modern capitalism, particularly in the US and UK, when it has to rely on the leverage for profits that is provided by rules on taxation, derivative financial products and other such mechanisms. It is not a question of the banks (or finance in general) versus the 'real economy'. The real capitalist economy is one of value-expansion, irrespective of its usevalue form. That is why it is easy for 'industrial' corporations to mould part of their operations into purely financial activities. This is especially easy when the lines between financial services, manufacturing operations and commercial activities are blurred for the major corporations. The origins of banking and financial profits are not the same as for industrial or commercial capital, but each division of capital is closely linked, providing business for the others. Simply to oppose finance, banks or derivatives is to miss the point that this is a single, integrated system of exploitation. In the US and the UK, furthermore, the financial sector is a key dimension of their economic power as imperialist countries. ${ }^{74}$ If this means that financial companies are favoured by AngloAmerican policy, then that can hardly be a surprise.

74. This economic and political-status factor is something that both the US and UK will fight to maintain, though the going will get much tougher for them in the coming years with the rise of 


\section{References}

ABP Investment Objectives, n.d., available at: <http://www.abp.nl/abp/abp/english/about_abp/ investments/about_investments/orobjectives.asp $>$.

Bank of England 2011, 'Financial Stability Report, June 2011', available at: <http://www .bankofengland.co.uk/publications/fsr/2011/fsr29.htm>.

Barnett-Hart, Anna Katherine 2009, 'The Story of the CDO Market Meltdown: An Empirical Analysis', Harvard University BA thesis, available at: <http://www.hks.harvard.edu/m-rcbg/ students/dunlop/2009-CDOmeltdown.pdf>.

BIS 2010a, 'Quarterly Review', December.

— 2010b, 'The Basel III Capital Framework: A Decisive Breakthrough', speech by Hervé Hannoun, deputy general manager of the BIS, in Hong Kong, 22 November.

- 2010c, 'Triennial and Semi-Annual Surveys: Positions in Global Over-the-Counter (OTC) Derivatives Markets at End-June 2010', 16 November.

Bryan, Dick and Michael Rafferty 2006a, 'Money in Capitalism or Capitalist Money?', Historical Materialism, 14, 1: 75-95.

2006b, Capitalism with Derivatives: A Political Economy of Financial Derivatives, Capital and Class, Basingstoke: Palgrave Macmillan.

CalPERS 2007, 'Fixed Income Overview', available at: <http://www.calpers.ca.gov/index.jsp?bc=/ investments/assets/fixed-income/fixedoverview.xml>.

Clark, Andrew, Heather Stewart and Elena Moya 2010, 'Goldman Sachs Faces Fed Inquiry Over Greek Crisis', The Guardian, 26 February, available at: <http://www.guardian.co.uk/business/ 2010/feb/25/markets-pressure-greece-cut-spending?INTCMP=SRCH>.

Crotty, James 2007, 'If Financial Market Competition Is So Intense, Why Are Financial Firm Profits So High?', Political Economy Research Institute Working Paper Series, 134, available at: <http:// www.peri.umass.edu/fileadmin/pdf/working_papers/working_papers_101-15o/WP134.pdf>.

Das, Satyajit 2006, Traders, Guns and Money: Knowns and Unknowns in the Dazzling World of Derivatives, Harlow: Pearson Education Limited.

dos Santos, Paulo L. 2009, 'On the Content of Banking in Contemporary Capitalism', Historical Materialism, 17, 2: 180-213.

Dowd, Kevin, John Cotter, Chris Humphrey and Margaret Woods 2008, 'How Unlucky Is 25-Sigma?', Journal of Portfolio Management, 34, 4: 76-80.

Duménil, Gérard and Dominique Lévy 2004, Capital Resurgent: Roots of the Neoliberal Revolution, translated by Derek Jeffers, Cambridge MA.: Harvard University Press.

European Commission 2010, 'Proposal for a Regulation of the European Parliament and of the Council on OTC derivatives, Central Counterparties and Trade Repositories', September, available at: <http://ec.europa.eu/internal_market/financial-markets/derivatives/index_en .htm>.

Financial Services Authority 2009, 'Reforming OTC Derivative Markets: A UK perspective', available at: <http://www.fsa.gov.uk/pubs/other/reform_otc_derivatives.pdf >.

Financial Times 2011, 'Swaps Bickering', 10 July, available at: <http://www.ft.com/cms/s/o/ 3803f2fc-abia-11eo-b4d8-oo144feabdco.html\#axzzimfHGJBIP>.

Gallu, Joshua and Christine Harper 2010, 'Goldman Sachs Sued by SEC for Fraud Tied to CDOs', Bloomberg, 16 April, available at: <http://www.bloomberg.com/news/2010-04-16/goldmansachs-sued-by-sec-for-fraud-over-mortgage-backed-cdos-shares-drop.html>.

economies that are seeking more political and economic independence, and which are seeing the growth of their own financial sectors, such as China. 
Greenberger, Michael 2008, 'Financial Speculation in Commodity Markets: Are Institutional Investors and Hedge Funds Contributing to Food and Energy Price Inflation?', Testimony before the Senate Committee on Homeland Security and Governmental Affairs, 24 June.

Grossmann, Henryk 1992 [1929], The Law of Accumulation and Breakdown of the Capitalist System, translated and abridged by Jairus Banaji, London: Pluto Press.

Helleiner, Eric 1994, 'Freeing Money: Why Have States Been More Willing to Liberalize Capital Controls than Trade Barriers?', Policy Sciences, 27, 4: 299-318.

Homer, Sydney and Richard Sylla 2005, A History of Interest Rates, Fourth Edition, Chichester: John Wiley and Sons.

Hull, John C. 2009, Options, Futures and Other Derivatives, Seventh Edition, Upper Saddle River: Pearson Prentice Hall.

ISDA 2001, 'Summaries of Market Survey Results, 2001 Year End Market Survey', available at: <http://www.isda.org/statistics/recent.html>.

— 2010, 'ISDA Comments on Sovereign CDS', available at: <http://www.isda.org/media/ press/2010/presso31510.html>.

Kindleberger, Charles P. 2000, Manias, Panics and Crashes: A History of Financial Crises, Fouth Edition, Chichester: John Wiley and Sons.

Kishan, Saijel 2008, 'Calpers to Boost Commodity Investments Through 2010', Bloomberg, 28 February, available at: <http://www.bloomberg.com/apps/news?pid=newsarchive\&sid= aps_cctZFFPo>.

Kliman, Andrew 2009, 'The Persistent Fall in Profitability Underlying the Current Crisis: New Temporalist Evidence', available at: <http://akliman.squarespace.com/persistent-fall >.

Lapavitsas, Costas 2006, 'Relations of Power and Trust in Contemporary Finance', Historical Materialism, 14, 1: 129-54.

Lapavitsas, Costas, A. Kaltenbrunner, D. Lindo, J. Michell, J.P. Painceira, E. Pires, J. Powell, A. Stenfors and N. Teles 2010, 'Eurozone Crisis: Beggar Thyself and Thy Neighbour', Research on Money and Finance Occasional Report, March, available at: <http://www.researchonmoney andfinance.org/media/reports/eurocrisis/fullreport.pdf >.

Larsen, Peter Thal 2007, 'Goldman Pays the Price of Being Big', Financial Times, 13 August, available at: <http://www.ft.com/cms/s/o/d2121cb6-49cb-11dc-9ffe-0000779fd2ac.html\#axzzımMiij6nm>.

Levine, Ross 2010, 'The Governance of Financial Regulation: Reform Lessons from the Recent Crisis', BIS Working Papers, 329, available at: <http://www.bis.org/publ/work329.pdf > .

London Metal Exchange 2011, 'History of the LME', available at: <http://www.lme.com/who_ ourhistory.asp >.

Marx, Karl 1974a, Capital, Volume 1, London: Lawrence and Wishart.

_ 1974b, Capital, Volume 3, London: Lawrence and Wishart.

Masters, Michael 2008, 'Financial Speculation in Commodity Markets: Are Institutional Investors and Hedge Funds Contributing to Food and Energy Price Inflation?', Testimony Before the Committee on Homeland Security and Governmental Affairs, 20 May.

McNally, David 2009, 'From Financial Crisis to World-Slump: Accumulation, Financialisation, and the Global Slowdown', Historical Materialism, 17, 2: 35-83.

Münchau, Wolfgang 2010, 'Time to Outlaw Naked Credit Default Swaps', Financial Times, 1 March, available at: <http://www.ft.com/cms/s/o/7b56f5b2-24a3-11df-8beo-00144feab49a.html\#axzzım Miij6nm>.

Norfield, Tony 2011a, 'The Economics of British Imperialism', Economics of Imperialism, 22 May, available at: <http://economicsofimperialism.blogspot.com/2011/05/economics-ofbritish-imperialism.html>.

— 2011b, 'Origins of the Greek Crisis', Economics of Imperialism, 24 June, available at: <http:// economicsofimperialism.blogspot.com/2011/o6/origins-of-greek-crisis.html>.

OECD 2010, 'Economic Outlook', May. 
Ontario Teachers' Pension Plan 2009, 2009 Annual Report, available at: <http://docs.otpp.com/ AnnualReport.pdf>.

Pennings, Joost M.E. and Matthew T.G. Meulenberg 1999, 'The Financial Industry's Challenge of Developing Commodity Derivatives', available at: <http://poseidono1.ssrn.com/delivery.php?I $\mathrm{D}=35608102608900010209701912001002910703401806205^{201609410600112111600109611511700007}$ $6031103068005099090080012091025114127016118007005098111 \& E X T=p d f>$.

Price Waterhouse Coopers 2010, 'The Total Tax Contribution of UK Financial Services', available at: <http://217.154.230.218/NR/rdonlyres/68F49A7E-8255-415B-99A8-1A8273D568D9/o/Total Tax3_FinalForWeb.pdf $>$.

Rogoff, Kenneth and Carmen Reinhart 2008, 'Banking Crises: An Equal Opportunity Menace', available at: $<$ http://www.aeaweb.org/assa/20og/retrieve.php?pdfid=245>.

SIFMA 2011, 'Global CDO Issuance', available at: <http://www.sifma.org/research/statistics.aspx>.

US Senate 2009, 'Excessive Speculation in the Wheat Market', Majority and Minority Staff Report, Permanent Subcommittee on Investigations, 24 June.

Wee, Gillian 2009, 'Harvard, Yale Endowments Decline 30\% on Private-Equity Losses', Bloomberg, 11 September, available at: <http://www.bloomberg.com/apps/news?pid=newsarchive\&sid=aif iKoimygqU>. 